\title{
PALEOCLIMATE, CONTROLS ON UPPER DEVONIAN SOURCE ROCK SEQUENCES AND STACKED EXTINCTIONS.
}

\author{
ORMISTON, Allen R., Amoco Production Research, P. O. Box 3385, \\ Tulsa, OK 74102, U.S.A.; KLAPPER, Gilbert, Dept. of Geology, \\ University of Iowa, Iowa City, IA 52242, U.S.A.
}

High quality ( $>2 \%$ TOC) Upper Devonian source rocks are developed in several sequence types. The commonest type, accounting for $70 \%$ of the studied examples is the transgressive sequence with a basal hiatus. Others include shallowing upward sequences $(12 \%)$, lacustrine sequences in faultcontrolled basins $(7 \%)$, distal slope sequences $(7 \%)$, and evaporite capped sequences $(4 \%)$.

Starting from the synthesis of Johnson, Klapper, and Sandberg (1985) it has been possible to demonstrate correlativity of Upper Devonian transgressive episodes globally. The marked association of epeiric sea Upper Devonian source rocks with transgressions heightens interest in their causation. Could they have been produced by glacio-eustatic sea-level change as Stanley (1984; 1988) implies? Quantitative paleoclimate modeling and isotopic paleotemperatures for the Upper Devonian suggest not. Modeling using $\mathrm{CCM}_{1}$ at NCAR, including five year seasonal cycles, suggests the absence of any large southern hemisphere ice volume. Because much of the Upper Devonian land mass was either in equatorial or high latitude regions, there was little development of monsoonal climates. Midlatitude cyclonic activity was also much less than at present, meaning less polar transport of moisture and drier polar areas. Precipitation maxima largely coincided with topographic elevations. In contrast to the Late Ordovician to earliest Silurian, there was no Upper Devonian perennial snow cover even over the high latitude southern land mass. This was in spite of winter land temperatures as low as $40^{\circ} \mathrm{C}$. in eastern Gondwana. In that area and elsewhere, there was thin winter snow cover which melted in late spring resulting in no build-up of snow cover to produce glaciation. This was mainly the consequence of low winter precipitation in Gondwana. High latitude sea surface temperatures were certainly cold enough to displace or exclude some organisms. However, in low latitude areas where Upper Devonian extinctions also took place, modeled sea surface temperatures range between $27^{\circ}$ and $34^{\circ} \mathrm{C}$. Such areas would have been refuges for any organisms displaced by cold, high latitude waters. The higher temperature values of low latitudes are convergent with the isotopic paleotemperatures determined by Brand (1989) using well preserved Upper Devonian brachiopods. Brand's determinations suggest temperatures even reaching lethal values for many plankton $\left(37^{\circ} \mathrm{C}\right)$. The extinction of reefs by the close of Frasnian time could have been partly a result of such elevated temperatures. Stacked extinctions of conodonts (Ziegler and Lane, 1987) and acritarchs may have been a further result. The loss of reefs, an important consumer of plankton, may have permitted a relative increase in plankton abundance crossing from more oceanic areas into epeiric seas, possibly contributing to high quality source rock deposition. 